\title{
Long term trends and breeding parameters of Gull-billed Tern Gelochelidon nilotica in three Italian coastal sites
}

\author{
Marcello Grussu $^{1 *}$, Francesco Scarton ${ }^{2}$, Emiliano Verza ${ }^{3}$, Roberto G. Valle
}

\begin{abstract}
Between 2001 and 2018 colonies of Gull-billed Tern were monitored in large wetland complexes of Veneto (lagoon of Venice and the Northern Po Delta) and Sardinia (western and southern) regions. Most of the colonies settled in man-made structures such as islets, levees, dams, located inside fish farms, fish ponds and salt pans. Laying took place around half May until early June (Veneto), with eggs occurring in the nests until half July (Sardinia). Colonies had 3-230 pairs, with several instances of isolated pairs; colonies were mono- or plurispecific, with other Charadriiformes. The number of eggs per clutch was $2.6 \pm 0.6(\mathrm{~N}=111,1 \mathrm{SD})$ in the Venice lagoon, $2.6 \pm 0.6(\mathrm{~N}=182)$ in the Po delta, $2.3 \pm 0.70(\mathrm{~N}=1007)$ in Sardinia; hatched eggs were $2.2 \pm 0.6$ $(\mathrm{N}=111), 2.0 \pm 0.7(\mathrm{~N}=182)$ and $1.7 \pm 0.67(\mathrm{~N}=40)$ per nest, respectively. The most important cause of breeding failure was due to flooding of nesting sites, due to the rapid increase of water levels inside fish farms and salt pans. During the 2001-2018 years, the Gull-billed Tern nested regularly in Sardinia, whereas in the Po Delta the first nesting occurred in 2001 and in the lagoon of Venice in 2008. The whole population ranged between 34 and 417 pairs until $2017(223.6 \pm 113.4, \mathrm{~N}=17)$, with a sudden increase up to almost 1,000 pairs in 2018; the overall trend is of strong increase $(\mathrm{p}<0.01)$, with an annual rate of $10.5 \%$.
\end{abstract}

Key words: breeding, long-term survey, fish farms, salt pans, Lagoon of Venice, Po Delta, Sardinia.

Riassunto - Tendenze a lungo termine e parametri di riproduzione della Sterna zampenere Gelochelidon nilotica in tre siti costieri italiani.

Tra il 2001 ed il 2018 sono state monitorate le colonie di Sterna zampenere presenti nelle zone umide sarde e venete. Le colonie erano in gran parte insediate su strutture artificiali quali isolotti e argini, all'interno di valli da pesca, saline o stagni, con copertura vegetale da rada a molto elevata. La deposizione si è verificata principalmente nella

${ }^{1}$ Gruppo Ornitologico Sardo, C.P. 160/C, 09045 Quartu Sant'Elena (CA), Italia.

${ }^{2}$ SELC Soc. Coop., via dell'Elettricità 3/d, 30175 Marghera (VE), Italia.

${ }^{3}$ Associazione Culturale Naturalistica Sagittaria, via all'Ara 15, 45100 Rovigo, Italia.

${ }^{4}$ Rialto 571, 30125 Venezia, Italia.

* Corresponding author: porphyrio@tiscali.it

(C) 2019 Marcello Grussu, Francesco Scarton, Emiliano Verza, Roberto G. Valle

Received: 29 June 2019

Accepted for publication: 7 October 2019

Online publication: 30 April 2020 prima metà di maggio, fino all'inizio di giugno (Veneto) e con uova presenti fino a metà luglio (Sardegna). Le dimensioni delle colonie erano comprese tra 3 e 230 coppie, con diversi casi di coppie singole. Le colonie erano sia monospecifiche che associate ad altri laro-limicoli. Le covate erano costituite da $2.6 \pm 0.6$ uova $(\mathrm{N}=111)$ in laguna di Venezia, $2.6 \pm 0.6$ uova $(\mathrm{N}=182)$ nel delta del Po veneto, $2.3 \pm 0.70$ uova $(\mathrm{N}=1007)$ in Sardegna. Il numero di pulcini sgusciati per nido è risultato pari a $2.2 \pm 0.6(\mathrm{~N}=111$ : laguna di Venezia), di $2.0 \pm 0.7(\mathrm{~N}=182$, delta del Po) e di $1.7 \pm 0.67$ ( $\mathrm{N}=40$, Sardegna). La principale causa di insuccesso riproduttivo è da attribuirsi alla sommersione dei siti, a causa di repentini aumenti dei livelli idrici entro valli da pesca o saline. La popolazione nelle tre aree di studio è rimasta complessivamente compresa tra $34 \mathrm{e}$ 417 coppie nel 2001-2017 (223.6 \pm 113.4$)$ con un drastico incremento fino a quasi 1000 coppie nel 2018. Nel complesso il trend della popolazione è di forte incremento $(\mathrm{p}<0.01)$, con un tasso annuo del $10.5 \%$.

Parole chiave: Sterna zampenere, Delta del Po, Laguna di Venezia, nidificazione, valli da pesca.

\section{INTRODUCTION}

The Gull-billed Tern Gelochelidon nilotica (Gmelin, 1789), hereafter GBT, has a cosmopolite distribution, with five subspecies recognized in the most recent review (Gochfeld et al., 2017). The European population, belonging to the nominal subspecies, has been recently estimated at 8,000-9,200 pairs in the 27 countries of the European Community (European Topic Centre on Biological Diversity, 2019) and at 16,600-21,200 pairs when considering the whole European area delimited to the east by the Urals (BirdLife International, 2019). According to recent estimates (Birdlife International, 2015) the species is considered as "increasing" over the last decade, thus being regarded as a "Lower Risk" in the European Red List of breeding birds.

In Italy, mostly due to the small extension of its nesting area, the GBT is considered as "Near Threatened" in the recent Red List (Peronace et al., 2012). The first confirmed nesting event dates back to the 1950's, with a few pairs found in the Valli di Comacchio wetlands (N Italy: Brandolini, 1950). In the following years the national population steadily increased up to 550 pairs in 2002, scattered among the coastal wetland complex of the western Emilia-Romagna, in Apulia and Sardinia as well, with a very few pairs nesting inland, far from the coast (Nardelli et al., 2015; Brichetti \& Fracasso, 2018). In the last decade the GBT continued to increase its nesting area, colonizing at first the northern sector 
of the Po Delta (meaning the one included in the administrative borders of the Veneto region: Verza, 2015) and after then settling in the Lagoon of Venice, which is nowadays the most northerly Italian nesting site (Valle et al., 2017).

The breeding biology of GBT has been studied in detail at several sites: North (Sears, 1978; Molina \& Erwin, 2006; Windhoffer et al., 2017) and central America (Palacios \& Mellink, 2007); Middle (Barati et al., 2012) and Far East (Wang et al., 2010); North Africa (Radi et al., 2011); Russia (Barbazyuk, 2005); Scandinavia, Black Sea and Mediterranean (Sánchez et al., 2004a). Quite differently, in Italy its breeding biology is still poorly known: if the trophic ecology (Fasola et al., 1989a and 1989b; Bogliani et al., 1990) and habitat selection (Fasola \& Canova, 1991 and 1992) were studied in detail, other aspects remain almost unknown.
The aim of this paper is thus that of increasing the knowledge of particular aspect of its breeding biology, as well as of long-term trends (2001-2018) of three populations nesting in the NE and SW Italy. Moreover, several considerations relevant to their conservation status and resulting from two decades of field observations have been expressed in the following pages.

\section{STUDY AREA AND METHODS} 1):

The study area is made of three well-defined sites (Fig.

1) the lagoon of Venice: a 55,000 ha lagoon, the largest around the Mediterranean, with 4,000 ha of saltmarshes islets, around 35,000 of shallow bottoms and about twenty fish farms, covering an additional 9,000 ha (Day et al., 2019);

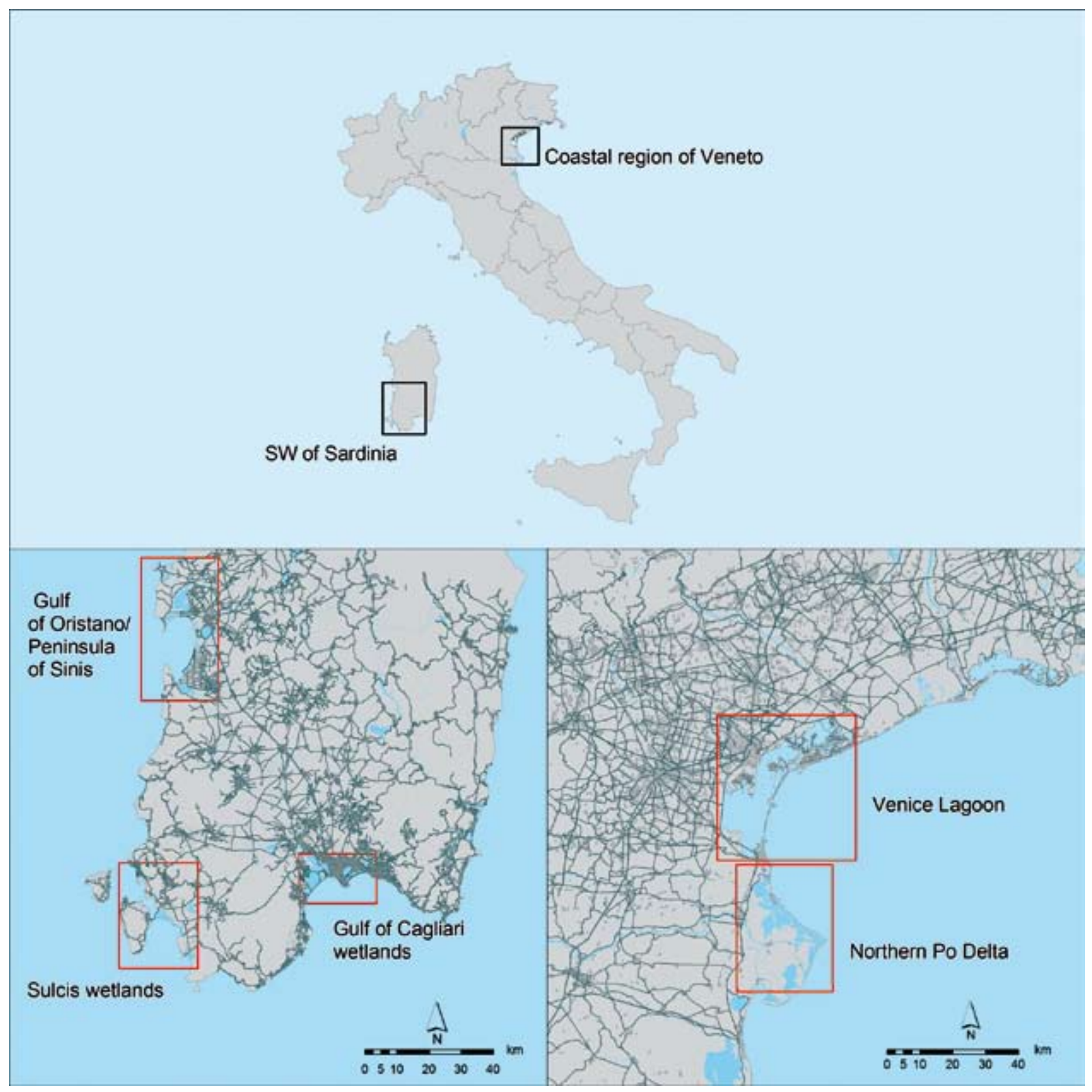

Fig. 1 - Study sites. / Siti oggetto di studio. 
2) the northern Po Delta, i.e. the surface of the delta extending from the Adige river mouth in the north to the Po di Goro river mouth in the south: it encompasses shallow lagoons, fish farms, river courses and large reclaimed areas used for agriculture (Scarton et al., 2018);

3 ) the western and southern Sardinian wetlands, namely: a) the Oristano Gulf/Sinis peninsula (from Porto Mandriola/Capo Mannu in the $\mathrm{N}\left(40^{\circ} 02^{\prime} \mathrm{N}, 8^{\circ} 23^{\prime} \mathrm{E}\right)$ to Stagno di San Giovanni in the S (39 $\left.49^{\circ} \mathrm{N}, 8^{\circ} 32^{\prime} \mathrm{E}\right)$, b) the Sulcis wetlands along the SW Sardinia coast, from Portoscuso in the $\mathrm{N}\left(39^{\circ} 11^{\prime} \mathrm{N}, 8^{\circ} 23^{\prime} \mathrm{E}\right)$ to the Porto Pino coastal pond in the $\mathrm{S}\left(38^{\circ} 57^{\prime} \mathrm{N}, 8^{\circ} 37^{\prime} \mathrm{E}\right)$; c) the Golfo di Cagliari wetlands, from La Maddalena/ Capoterra in the $\mathrm{W}$ $\left(39^{\circ} 09^{\prime} \mathrm{N}, 9^{\circ} 01^{\prime} \mathrm{E}\right)$ to the Quartu pond in the E $\left(39^{\circ} 13^{\prime} \mathrm{N}\right.$, $\left.9^{\circ} 13^{\prime} \mathrm{E}\right)$. Overall, this site includes several shallow water coastal ponds and lagoons, along with some saltpans still in use.

In all these three sites regular surveys of nesting waders and seabirds have been made by the Authors of this work across the last three decades (see Scarton \& Valle, 2015; Scarton et al., 2018; Grussu1995; Grussu \& Gruppo Ornitologico Sardo, 2017). For the Lagoon of Venice and the northern Po Delta data collection for GBT began in 2001, year of its first nesting event; in Sardinia, it dates back to the '80s. In 2017-2018, the Authors co-ordinately made specific field activities in GBT colonies for this work.

Surveys were made by the Authors visiting each colony at least twice during the breeding season (May-July), counting all the nests containing eggs and/or chicks (apparently occupied nests: see Steinkamp et al., 2003). Number of pairs has been considered equal to that of counted nests; we recognize this statement may not be always correct (Frederick et al., 2006). In 2017-2018, in the Lagoon of Venice an unmanned aerial vehicle (drone) was used to reduce disturbance to the colonies during the surveys (Valle \& Scarton, 2018).

Visits to the colonies were limited to the minimum time needed to collect data, and always in absence of heavy rains or high tides. Data were collected by RV and FS in the Venice lagoon; EV in the Po Delta; MG in Sardinia. For each study site, we recorded the number of breeding pairs and colonies, other nesting species and the habitat type used; data on the breeding phenology, nesting site selection, nesting success (number of hatched and fledged young per nest) and possible threats observed in the field. Area and percentage of vegetation coverage of colonies sites, consisting mostly in islets, mounds and levees, were also measured; the elevation of the colony site above the water level was also visually estimated during field visits. Morphological characteristics of colonies sites were compared with those of other, non-used sites occurring in a radius of $500 \mathrm{~m}$. For randomly selected nests, habitat selection was studied recording substrate type (sand, mud, vegetation debris, etc.); vegetation coverage was visually estimated; distance from the edge of the colony site, from the nearest nest, from conspecific and other species nests was also measured (Valle \& Scarton, 1999). For each GBT selected nest, the same parameters were measured in another, randomly selected point in a radius of $5 \mathrm{~m}$ (Valle \& Scarton, 1999).
To calculate trends across the 2001-2018 years, we used TRIM (TRends and Indices for Monitoring data), which is a program used to determine species' population trends; it allows for missing counts using estimation, and yields yearly indices and standard errors using Poisson regression (version 3.53: Pannekoek \& van Strien, 2005). Trends were not calculated for the Venice Lagoon, given the very few years with breeding records. The multiplicative trend estimate (trend value) in TRIM is converted into one of the following categories to facilitate its interpretation further: strong increase - moderate increase - stable - uncertain - moderate decline -steep decline. According to Vořišek et al. (2008), since complete counts were available it has been selected the Time Effects Model options, with "over dispersion" set to "off" mode and "serial correlation" set to "on" mode.

Data are expressed as mean $\pm \mathrm{SD}$; significance of comparisons were checked using the Mann-Whitney U-test, using the SPSS software. A probability level $<0.05$ has been considered significant.

\section{RESULTS \\ Lagoon of Venice}

In this site the GBT probably nested for the first time in 2006, in a fish farm (Panzarin, pers. comm.); the first confirmed event dates to 2008 , with other nesting records in 2009, 2011 and 2013-2015, always inside fish farms. Outside fish farms, the GBT nested only once, with a single pair found in a mixed colony with Common Tern Sterna hirundo and Little Tern Sternula albifrons, located in a dredge island, i.e. an artificial, intertidal island made with the use of sediments dredged from lagoon channel (Scarton et al., 2013). In 2018 two colonies, one with 228 and the other with 58 pairs, were located inside two fish farms at $8 \mathrm{~km}$ one from the other (Figs. 2 and 3 ).

The largest colony hosted also a few pairs of Common Redshank Tringa totanus, while the smallest was inside a mixed colony, with Common Tern (172 pairs) and Common Redshank (18 pairs). The largest GBT colony occupied 15 mud mounds, each one hosting $15 \pm 23$ nests (median $=10$, range $=1-93$ ) and located inside a large, shallow brackish basin used for non-intensive fish rearing; the overall mound surface was $464 \mathrm{~m}^{2}$ (mean=31 \pm 21 ; median $=24$; range $=7-87$ ).

The distance of the mounds from the mainland was $0.8 \mathrm{~km}$ at a minimum. Nest density was $0.4 \pm 0.3$ nests $/ \mathrm{m}^{2}$ (median $=0.3$; range $0.1-1.1$ ).

The 15 mounds used by GBT were significantly (Fig. 4) smaller and higher above the water level than nonoccupied mounds occurring in the $500 \mathrm{~m}$ radius $(\mathrm{N}=47$ : Fig. 4). On the contrary, bare ground $\%$ or vegetation coverage \% did not differ (Fig. 4). At mounds used by birds, the vegetation coverage was due to alophylous and nitrophylous species (Sarcocornia fruticosa, Suaeda maritima, Salicornia veneta): around a sample of 111 nests, vegetation coverage in a square meter surrounding each nest was $94 \pm 13 \%$ (min-max: $13-100 \%$ ). As a consequence, nesting pairs made a cup using small vegetation stems; only in the few bare areas GBT made a small depression, without any lining material. 


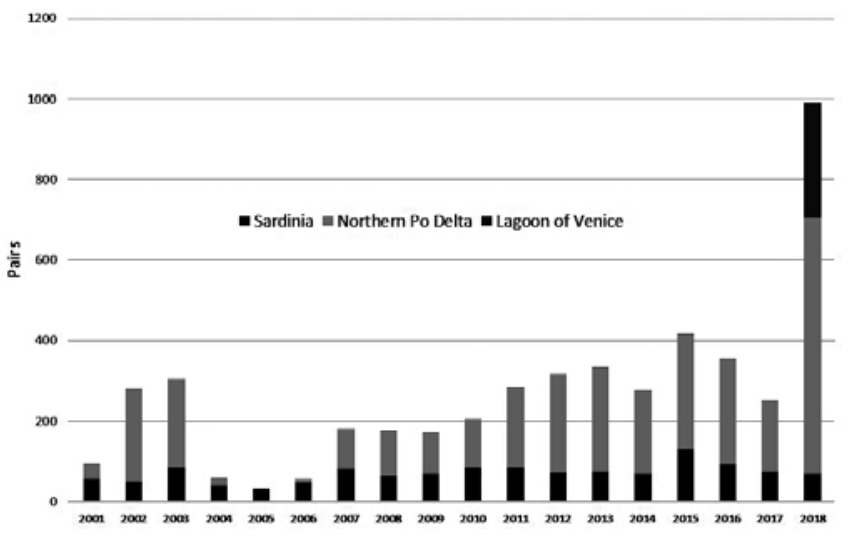

Fig 2 - Number of Gull-billed Tern pairs nesting in the three study sites. Some data for the Lagoon of Venice are not visible for scale reasons (see text). / Numero di coppie di Sterna zampenere nidificanti nei tre siti di studio. Alcuni dati per la Laguna di Venezia non sono visibili per motivi di scala (vedi testo).

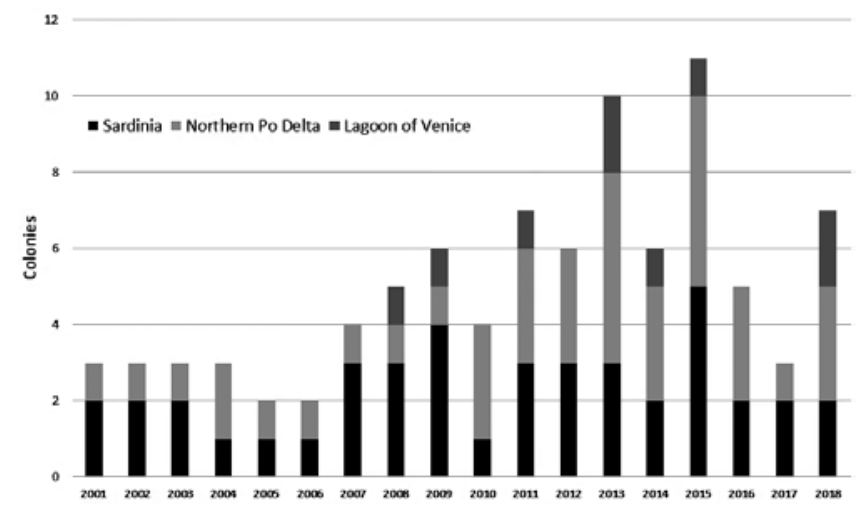

Fig. 3 - Number of colonies occurring in the three study sites. / Numero di colonie presenti nei tre siti di studio.

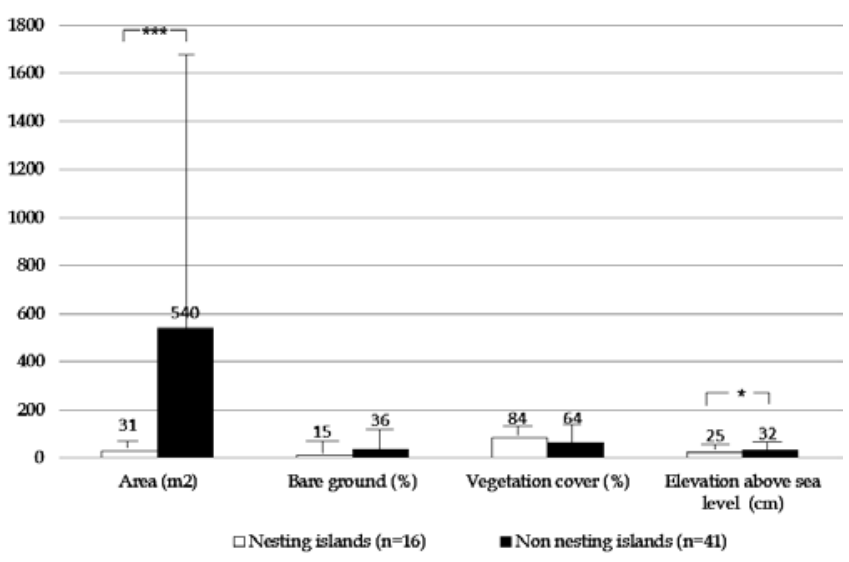

Fig. 4 - Colony site selection of Gull-billed Terns in the Lagoon of Venice in 2018. Mean \pm SD; Mann-Whitney U-test. *) $\mathrm{p}<0.05$; ***) $\mathrm{p}<0.001$. / Selezione del sito della colonia di Sterne zampenere nella Laguna di Venezia nel 2018. Media \pm SD; U-test di Mann-Whitney. *) $\mathrm{p}<0,05 ; * * *) \mathrm{p}<0.001$.
Nesting distance from the surrounding water was $0.24 \pm 0.17 \mathrm{~m}$ (min-max: 0-0.7 $\mathrm{m}, \mathrm{N}=111)$; the intraspecific distance was $0.8 \pm 1.4 \mathrm{~m}(0.2-15.0, \mathrm{~N}=111)$. In 2018 the mean number of eggs per nest was $2.6 \pm 0.6$ (median $=3$; $\min -\max =1-4 ; \mathrm{N}=111$ ); laying began in the second decade of May and hatching during the first half of June. In a sample of 111 nests, hatched chicks were on average $2.2 \pm 0.6$ (range: $0-4$ ), while the fledged young were on average 1.4 .

Non-systematic observations suggest that the most important feeding areas for adults were fish farm ditches, with brackish or fresh water, and large fields used for agricultural use close to the colonies, but sometimes up to 8 $\mathrm{km}$ faraway. We never observed GBT feeding in the large, lagoon basins, despite these were at close distance from the colonies.

\section{Northern Po Delta}

Here GBT began to nest for the first in 2001, inside a fish farm (Fracasso et al., 2003). Since that year, the nesting population grew up, using each year several fish farms. Between 2001 and 2017 the mean number of nesting pairs was $212 \pm 138$ (range: $40-380$; median: 208; data for 2004, 2005 and 2006 years not included, since only estimates for each colony are available).

Each year the number of colonies was $2.3 \pm 1.5$ (range: 1-5; median: 2, N=41). In 2018 a dramatic increase was observed in the number of breeding pairs, but not in that of colonies: 653 pairs were in three colonies (Figs. 2 and 3 ). The mean dimension of the colonies was $86 \pm 83$ pairs (median: 67; range: 1-380; $\mathrm{N}=35$, years 2004-2006 not included). The GBT nested always inside fish farms, using mounds or small levees, only occasionally saltmarsh islets. Vegetation coverage in the first two types of nesting sites was very low, mostly due to Salsola soda and to a few Phragmites australis stems. Colony sites were in the centre of large, brackish basins, thus being quite far from the surrounding inlands where several potential predators, such as Red Fox Vulpes vulpes, Weasel Mustela nivalis, Cat Felis catus, Norway Rat Rattus norvegicus lived.

Nesting occurred most of the time in mixed colonies, with Mediterranean Gull Larus melanocephalus (minimum interspecific nest distance: $2 \mathrm{~m}$ ), Common Tern (2.4 $\mathrm{m})$, Little Tern (4.6 m), Kentish Plover Charadrius alexandrinus $(8.2 \mathrm{~m})$, Pied Avocet Recurvirostra avosetta (1.2 $\mathrm{m})$, Black-winged Stilt Himantopus himantopus (1.8 m), Common Redshank (0.7 m), Collared Pratincole Glareola pratincola $(9 \mathrm{~m})$. Laying occurred mostly in the first half of May, but in some years it could extend until the beginning of June; this was the case when replacement clutches were made, after the loss of nests due to strong meteorological events. Sites used by the GBT to nest had a vegetation coverage ranging from $0 \%$ until almost $100 \%$.

Nests appeared to be built in different ways, according to the elevation above water level of the sites: when built on bare-ground elevated sites, nests were often without any lining material. At lower-elevation sites, nests consisted of a cup lined with vegetation stems, and were built both on the bare ground and on the top of alophylous vegetation. 
Density of nests at 16 sites ranged between 0.01 and 0.85 nests $/ \mathrm{m}^{2}$, with a mean of $0.31( \pm 0.27, \mathrm{~N}=16)$. Sites used by the GBT to nest $(\mathrm{N}=16)$ were not significantly different from non-used sites $(\mathrm{N}=46)$ if area, $\%$ of vegetation coverage or bare ground are considered (Mann-Whitney U-test: Fig 5). Differences in the height above the water level was at the threshold of significance, with occupied sites lower than non-occupied sites (Fig. 5). Examples of the different colony sites used by GBT are shown in Figs. 6 and 7.

Number of eggs/nest was on average $2.6 \pm 0.6$ (median: 3; min-max: 1-4; $\mathrm{N}=182$ ), while the dimensions were $48.2 \pm 1.6$ x $34.6 \pm 0.8 \mathrm{~mm}$ (min-max: $45.2-52.6$ and 33.2$36.7 \mathrm{~mm}$, respectively; $\mathrm{N}=23$ ). In 2018, number of hatched eggs per nest was $2.0 \pm 0.7$ (range: $0-4$, median: 2 ).

The feeding area includes mostly brackish or freshwater ditches and small channels, along with agricultural fields, close to the colonies; nevertheless, an observation of eight adults foraging at $27 \mathrm{~km}$ from the nearest colony suggests the feeding range could be longer.

The trend observed for the GBT breeding population in the Northern Po Delta is shown in Fig. 2; with TRIM, it is classified as "strong increase", $p<0.01$, with an annual rate of $+14.3 \%$.

\section{Sardinian wetlands}

Until the beginning of the XX century, the GBT was considered as rare in Sardinia (Lepori, 1882; Arrigoni degli Oddi, 1929). The first individuals, probably summering, were noticed in the '60s in the Stagno di Molentargius/Cagliari and in the Gulf of Oristano (Walter, 1964; Mocci Demartis, 1973). The first confirmed nesting was observed in 1971, with two pairs breeding in the saltpans of Cagliari (Schenk, 1976). Nesting continued in the same sites in the following years, with 13 pairs in 1975, 25 in 1976 (Schenk, 1976), 90 in 1980 (Massa \& Schenk, 1983) and 111 in 1984 (Fasola, 1986). After that, nesting took place at 1-2 sites in wetlands around Cagliari (saltpans of Cagliari and Quartu; coastal pond of Molentargius), with a total population ranging from a few tens of pairs to 127

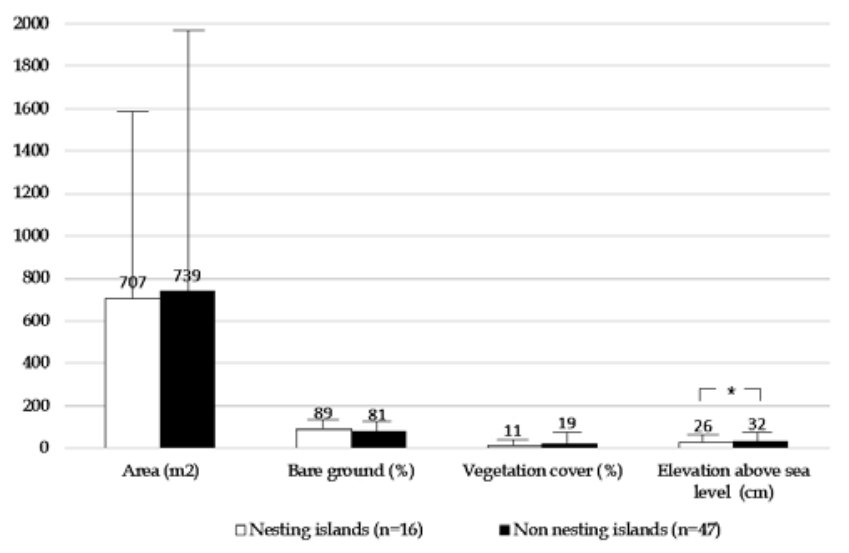

Fig. 5 - Colony site selection of Gull-billed Terns in the Po Delta in 2017-2018. Mean \pm SD; Mann-Whitney U-test. *)p $<0.05$. / Selezione del sito della colonia di Sterne zampenere nel Delta del Po nel 20172018. Media $\pm \mathrm{SD}$; U-test di Mann-Whitney. *) $\mathrm{p}<0,05$. pairs. Other important, single nesting sites were found in 1995 (115-130 pairs), in 1990 (118-123 pairs) and 2000 (102-120 pairs).

A second complex of nesting sites lays in the Gulf of Oristano (western Sardinia). Here the first nesting event dates back to 1986 , when a colony with 25 pairs settled in the Sale Porcus costal pond (Gustin, 1988; Grussu, unpublished). In the following years, nesting occurred regularly until the end of the XX century, but only occasionally since then. Here, colonies frequently moved among the sites, such as coastal ponds of Sale Porcus, s'Ena Arrubia, Santa Giusta, and those surrounding the Laguna di Cabras, most likely due to frequent changes in the water levels in the basins, where colony sites were used the previous years.

Overall, in the Gulf of Oristano nesting during the 1986-2018 period took place in 25 years $(75.8 \%$ of the years); the population ranged between 3 and 135 pairs, with a maximum observed in 1991 in the coastal pond of Sale Porcus. The other years with high number of breeding pairs were 1990 (90-100 pairs in the s'Ena Arrubia coastal pond), in 1988 (90-92 at two sites), in 1996 (70-90 at one site), in 2015 (62-85 at two sites), in 1993 (70-80 at three sites), in 2003 (75 at one site) and in 2016 (80 at one site).

The last complex of nesting sites is in the Gulf of Palmas (southwestern Sardinia), where after the observations of summering birds, in 1991 from 2 to 3 pairs began to nest in Mullargia coastal pond. Until 1999 nesting took place regularly at three different sites (coastal ponds of Mullargia; saltpan and lagoon of Sant'Antioco) with a maximum of 31 pairs in 1994. After that year, only a few summering birds were observed, without any proof of confirmed nesting. The results for the Sardinian GBT yearly counts are shown in Fig. 2; the trend estimated with TRIM for the 2001-2018 years is of "moderate increase", with an annual rate of $+3.6 \%$.

Colonies were located either on islets covered with saltmarsh vegetation or in bare muddy/sandy islets, occurring inside coastal ponds, lagoons and saltpans; nests were made from just a few $\mathrm{cm}$ from the water level up to almost $1.70 \mathrm{~m}$. In 1989, a colony with 38 pairs used small islets covered with Ficopomatus enigmaticus. Colony dimensions ranged between 3 and 135 pairs, with several cases of isolated pairs: the mean was $11 \pm 30$ pairs in the Gulf of Palmas (range $=1-30 ; N=15$ ), $28 \pm 20$ in the Gulf of Cagliari (range $=1-89 ; \mathrm{N}=63$ ); $42 \pm 26$ (range=3-135; $\mathrm{N}=22$ ) in the Gulf of Oristano.

Colonies were usually multispecific, with other nesting waders and seabirds such as Slender-billed Gull, Common Tern, Little Tern, Pied Avocet, Black-winged Stilt, Kentish Plover; less frequently, given their small Sardinian populations, with Common Redshank, Blackheaded Gull Chroicocephalus ridibundus, Mediterranean Gull and Collared Pratincole. It may also nest in the same islets used for nesting by Yellow-legged Gull Larus michahellis and Flamingo Phoenicopterus roseus.

Nests were often built on the bare ground or on low vegetation (Halimione sp., Salicornia sp., Limonium sp.), without lining material or sometimes with material found close by: shells, pebbles, pieces of dry mud, twigs, leaves of Posidonia oceanic and Typha sp.; wooden chips; small bones of gulls (probably Slender-billed Gull), feathers 
(Larus sp., Flamingo, Cormorant Phalacrocorax carbo), mummified chicks of Slender-billed Gull; small salt agglomerates.

Nests of GBT were located 2-7 $\mathrm{m}$ apart one from the other, only occasionally at shorter distance $(5$ nests in 3 $\mathrm{m}^{2}$ ). In mixed colonies, some nests of GBT were made close to those of other species, to a minimum of $5 \mathrm{~cm}$ from a Slender-billed Gull nest; generally, distances were nevertheless higher, up to $8 \mathrm{~m}$.

Colony sites were used from the beginning of May; the earliest laying took place in the first decade of this month (earliest date of nests with eggs: 11 May), until the half of July. After that, replacement clutches may be laid until the half of July. Number of eggs per nest was $2.3 \pm 0.70$ $(\mathrm{N}=1007$ : Tab. 1). The first chicks were observed at the beginning of June (earliest date: 4 June).

Only few data are available on reproductive success: $2.11 \pm 0.6$ chicks/nest were observed in a sample of nine nests, and $1.61 \pm 0.6$ chicks/nest in a sample of 31 nests. Predations of GBT chicks/eggs were observed, caused by Yellow-legged Gull and Hooded Crow Corvus cornix; a colony of 40 pairs was displaced by a growing colony of Flamingo, nesting in the same islet.

Regarding the feeding habitats, adults were observed hunting in areas close to the colonies, such as small wetlands, cultivated fields and rice fields up to $4-5 \mathrm{~km}$ far away.

\section{DISCUSSION AND CONCLUSIONS}

Several aspects of the breeding biology of GBT were similar among the three study sites. In particular, colony sites were almost always represented by islets, mounds and levees, made with sediments coming from dredging activities performed in the close surroundings; this type of sites was already recorded in other studies, both in Italy (Fasola \& Canova, 1991) and abroad (Eyler et al., 1999; Sánchez et al., 2004b). Only occasionally, the species used saltmarsh islets, covered with thick vegetation, or other highly vegetated sites. Nevertheless, at the artificial sites which were commonly used, the vegetation coverage was extremely variable, ranging from almost 0 on small or very small sites (i.e. $<50 \mathrm{~m}^{2}$ ), up to about $60 \%$ in the larger sites.

Both at Venice lagoon and northern Po Delta sites, patches of vegetation surrounding the nests were used by chicks to find shelter from sun light and to hide from a possible aerial predator, as observed when a drone was used in the surveys (Valle \& Scarton, 2018). This confirms previous findings of some other studies, which observed a positive association between vegetation coverage and reproductive success (Barati et al., 2012); nevertheless, Windhoffer et al. (2017) found opposite results at North Carolina colonies. A trade-off between possibility of chick concealment but also of terrestrial predator occurrence must be hypothesized regarding the role of vegetation around the nests.

Despite we recognize our number of samples was low, the estimated reproductive success at our study sites seems adequate to maintain a self-sustaining population; Eyler et al. (1999) considered that for this purpose 1-1.2 young were needed, since these values were found in the closely related species Roseate Tern Sterna dougallii. In the scientific literature, values of 1.35 fledged young/ pair (Brichetti \& Fracasso, 2006) were reported for Italian sites, while Møller (1975, in Cramp, 1985) found 1.48 young in a Danish site. At the opposite, Eyler et al. (1999)

Tab. 1 - Clutch and brood size of Gull-billed Terns in Sardinian wetlands. / Dimensione delle covate di Sterna zampenere nelle zone umide sarde.

\begin{tabular}{|c|c|c|c|c|}
\hline & Gulf of Cagliari & Gulf of Oristano & Gulf of Palmas & Total \\
\hline & \multicolumn{4}{|c|}{ No. of nests } \\
\hline \multicolumn{5}{|l|}{ No. of eggs } \\
\hline 1 & 112 & 57 & 5 & 174 \\
\hline 2 & 203 & 138 & 24 & 365 \\
\hline 3 & 218 & 207 & 32 & 457 \\
\hline 4 & 5 & 3 & 2 & 10 \\
\hline 5 & - & - & 1 & 1 \\
\hline Nests checked & 538 & 405 & 65 & 1007 \\
\hline Mean eggs/nest & 2.21 & 2.39 & 2.49 & 2.36 \\
\hline \multicolumn{5}{|l|}{ No. of chicks } \\
\hline 1 & 15 & 1 & & 16 \\
\hline 2 & 13 & 6 & & 19 \\
\hline 3 & 3 & 2 & & 5 \\
\hline Nests checked & 31 & 9 & & 40 \\
\hline Mean chicks/nest & 1.61 & 2.11 & & 1.7 \\
\hline
\end{tabular}


observed that a success of 0.5-0.7 fledged young/pair was not enough to maintain a GBT population in coastal Virginia (USA).

In both the northern Adriatic sites the good reproductive success observed in 2017-2018 was probably due to: low nest predation caused by mammals or birds; favourable meteorological conditions during the nesting season, without heavy rains or storms; negligible occurrence of fish farm management works, such as rise of water levels inside the basins or islets reshaping, in the May-June months. This was due in part to the active cooperation of fish farm managers, who were instructed about the importance of preserving the colony sites in those months. It is thus crucial, for a species that commonly uses man-made structures to nest (see Molina \& Erwin, 2006 in the USA; Radi et al., 2011 in Morocco; Sadoul, 2016 in France) a strong cooperation among conservation bodies and private owners.

About predation, only in the Sardinian sites gulls and crows were observed several times eating eggs or chicks, but it is not possible to assess the real impact of these events on the reproductive success of GBT.

The population nesting at our three study sites showed overall an increase of $10.1 \%(\mathrm{p}<0.01$ : strong increase $)$ between 2001 and 2018, but with different dynamics. In the two northern Adriatic sites, where the species began to nest in 2001, the GBT showed a marked increase between 2015-2018, rising from 250 pairs to more than 900 , mostly due to the arrival in 2018 of a large number of adults. Generally, GBT has been regarded as a low-fidelity breeder, due to the often ephemeral and unpredictable nature of its preferred colony sites (Cramp, 1985; Molina \& Erwin, 2006; Windhoffer et al., 2017), despite sometimes the species shown at the opposite a remarkable breeding site fidelity (Sánchez et al., 2004b). In any case, the lack of observations of ringed or otherwise marked birds do not allow us to know where the adults arrived in 2018 came from; we can only remark that in the same year the French Mediterranean breeding sites showed a peak of occurrence of GBT (Pin, 2018), whereas in the very last years the species disappeared from a formerly important breeding sites such as the Danube Delta (Marinov et al., 2019). This suggests that important displacements of breeding adults is taking place in the whole Mediterranean, but simultaneous and coordinated supra-national surveys are needed to confirm this hypothesis.

The Sardinian population did not follow the same trend of the northern Adriatic sites; while being in moderate increase over the long-term period (2001-2018), it shows a decrease between 2015 and 2018. The environmental conditions of the wetland sites used by GBT apparently did not seem to deteriorate, thus the decrease of the species must be due to other driving factors.

Overall, in 2018 the three study sites hosted about 1,000 pairs, a value much higher than the 543-551 pairs breeding in 2002, the last year for which an Italian estimate is available (Nardelli et al., 2015). Recently the GBT nested in the southern Po Delta (Emilia-Romagna region) and occasionally in Sicily and Apulia (Brichetti \& Fracasso, 2018). Given the chronic absence of a nationwide monitoring program, despite the species is included in the Annex I of the Birds Directive 147/09/EC, it is not possible to make statements about the size and trend of the whole Italian population, with obvious negative effects on the forthcoming Italian Report on the Birds Directive implementation.

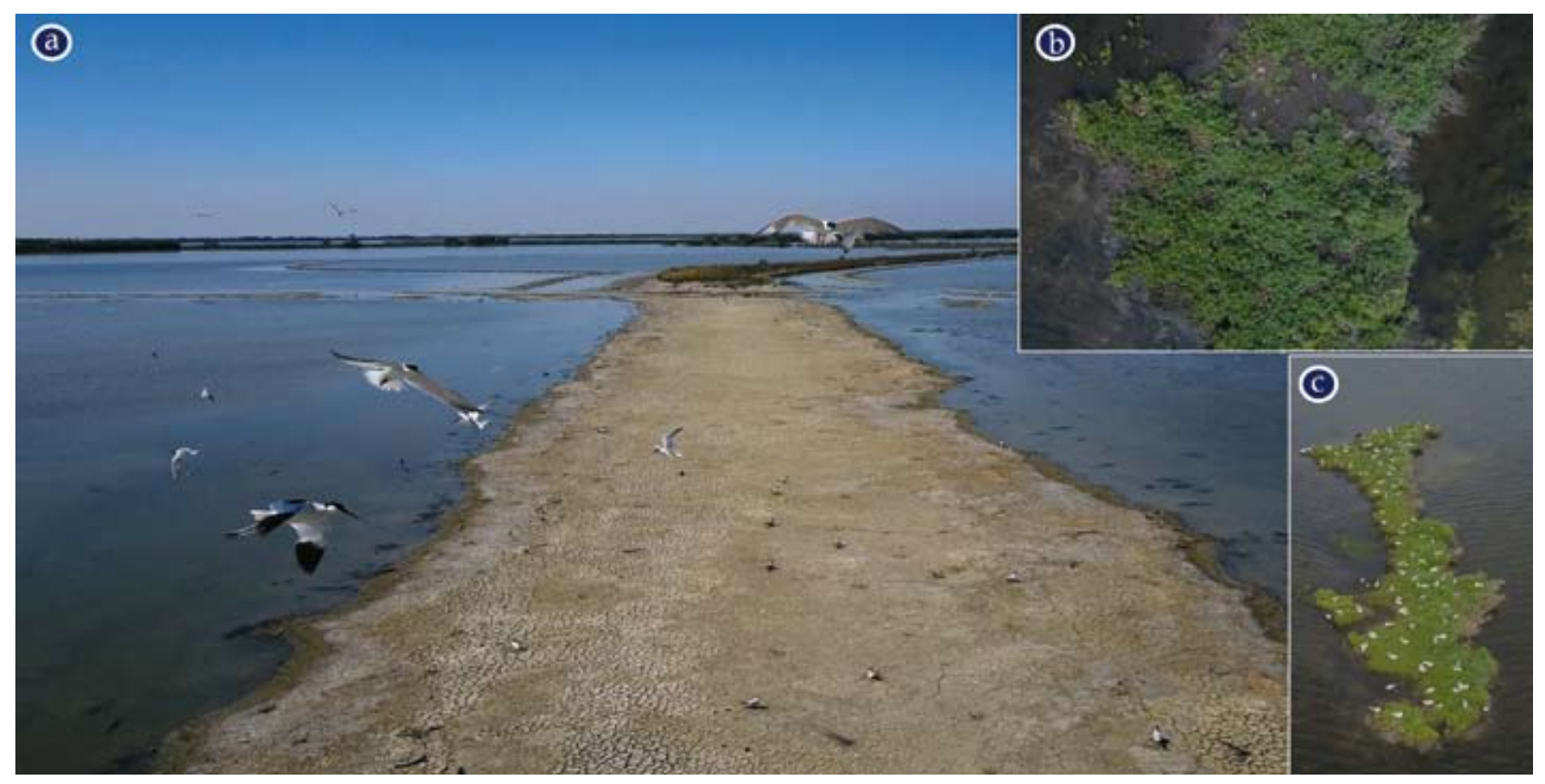

Fig. 6 - Differences in colony site morphology and colony structure:loose colony on bare-ground site (a, with an Avocet in the fore ground), and dense colony on highly vegetated sites (b, c). All the pictures were taken by drone. / Differenze nella morfologia del sito della colonia e nella struttura della colonia: colonia lassa su suolo nudo (a, con un avocetta in primo piano) e colonia densa su siti altamente vegetati $(\mathrm{b}, \mathrm{c})$. Tutte le foto sono state scattate da drone. 


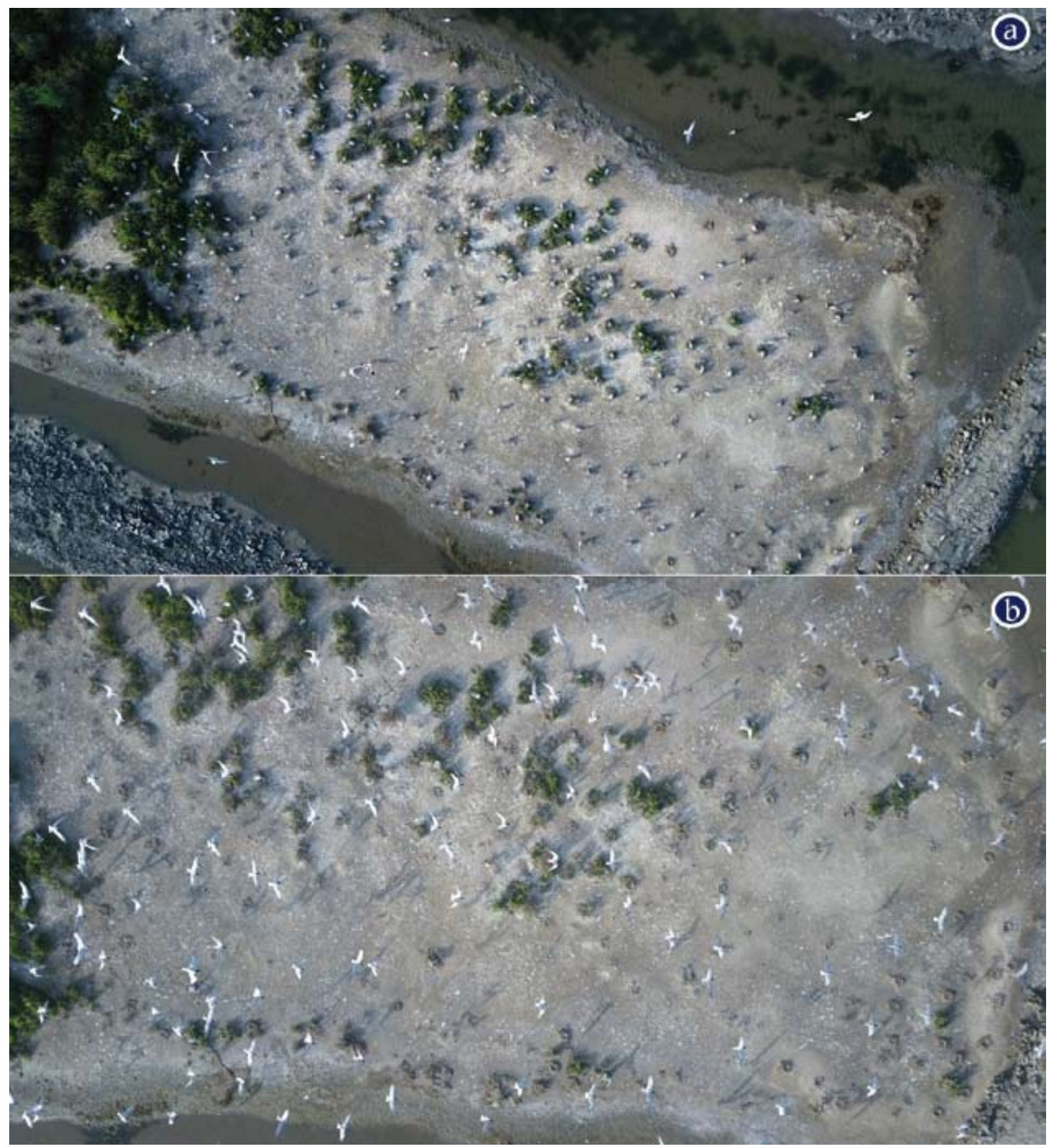

Fig. 7 - Dense colony on a bare-ground colony site (a). In b, a close-up of the same colony is shown, where nests with eggs were counted with a drone. / Colonia densa su un sito con terreno nudo (a). In b, viene mostrato un primo piano della stessa colonia, dove $\mathrm{i}$ nidi con le uova venivano contati con un drone.

Nevertheless, we can compare the data we collected over almost twenty years with the findings of Gustin et al. (2016), who analysed the conservation status of the Italian birds and set a minimum viable population (MVP) for GBT of 570 pairs, for the Italian continental population, and of 200 pairs for the Sardinian one. These values were reached, and exceeded, only in 2018 in the Italian peninsula, while they were never reached in Sardinia over the 2001-2018 period, despite both populations were showing a long-term increas- ing trend. This could probably cast some doubts about the applicability of the above reported MVP values for guiding conservation actions for this species. Flather et al. (2011) already warned against an acritical use of MVP in conservation planning; despite a detailed analysis of this topic is well beyond our expertise, we want to underpin the crucial importance of collecting field data with cooperative efforts and during long-term monitoring, an issue particularly important for colonial breeders such as the GBT. 


\section{Acknowledgments}

Most of the activities were self-financed. We are grateful to Rosalino Garbi, Roberto Grussu, Antonio Locci, Francesco Mascia, Roberto Meloni, Alberto Palumbo, Lucio Panzarin, Giuseppe Penzo, Mauro Pregnolato, Rossana Rossi, Luca Sattin, Eri Tessarin, Daniele Zanellato, Giuliano Zanellato, Gianluca Zappaterra, Maurizio Zerbinati and all the members of Associazione Sagittaria. The owners and managers of fish farms kindly gave permission and facilitated field activities in their premises. The help of the Editor and of an anonymous Referee greatly improved the original manuscript.

\section{REFERENCES}

Arrigoni degli Oddi E., 1929 - Ornitologia Italiana. Hoepli, Milano.

Barati A., Etezadifarb F. \& Esfandabad B. S., 2012 - Nestsite selection and hatching success at a mixed-species colony of Black-winged Stilts Himantopus himantopus and Gull-billed Tern Gelochelidon nilotica. Avian Biology Research, 5 (2): 142-146.

Barbazyuk E. V., 2005 - Responses to human disturbance from nesting Gull-billed Terns. Ethology, 14 (2): 221230.

Birdlife International, 2015 - European Red List of Birds. Office for Official Publications of the European Communities, Luxembourg.

Birdlife International, 2019 - Species factsheet: Gelochelidon nilotica. Downloaded from $<\mathrm{http}$ ://www.birdlife. org $>(07 / 04 / 2019)$.

Bogliani G., Fasola M., Canova L. \& Saino N., 1990 Food and foraging rhythm of a specialized Gull-billed Tern population Gelochelidon nilotica. Ethology, Ecology and Evolution, 2: 175-181.

Brandolini A., 1950 - Note di ornitologia Ravennate (anni 1948 e 1949). Rivista Italiana di Ornitologia, 20 (2): 58-61.

Brichetti P. \& Fracasso G., 2006 - Ornitologia italiana. 3. Stercorariidae - Caprimulgidae. Alberto Perdisa Editore.

Brichetti P. \& Fracasso G., 2018 - The Birds of Italy. Volume 1. Anatidae-Alcidae. Edizioni Belvedere, Latina.

Cramp S. (ed.) 1985 - Handbook of the birds of Europe, the Middle East, and North Africa: the birds of the Western Palearctic. Oxford University Press, Oxford, IV.

Day J. W., Ibáñez C., Pont D. \& Scarton F., 2019 - Status and Sustainability of Mediterranean Deltas: The Case of the Ebro, Rhône, and Po Deltas and Venice Lagoon. In: Coasts and Estuaries, The future. Wolanski E., Day J. W., Elliott M. \& Ramachandran R. (eds.). Elsevier: 237-249.

European Topic Centre on Biological Diversity, 2019 Reporting under Article 12 of the Birds Directive (period 2008-2012). Introduction to status and trends of bird species. <http://bd.eionet. europa.eu/.> (Downloaded: 4/5/2019).

Eyler T. B., Erwin E. R., Stotts D. B. \& Hatfield J. S., 1999 - Aspects of Hatching Success and Chick Survival in Gull-billed Terns in Coastal Virginia. Waterbirds, 22 (1): 54-59.
Fasola M., 1986 - Distribuzione e popolazione dei Laridi e Sternidi nidificanti in Italia. Istituto nazionale di biologia della selvaggina, Supplemento Ricerche di Biologia della Selvaggina, Ozzano dell'Emilia, 11.

Fasola M. \& Canova L., 1991 - Colony site selection by eight species of gulls and terns breeding in the "Valli di Comacchio" (Italy). Bollettino di zoologia, 58 (3): 261-266.

Fasola M. \& Canova L., 1992 - Nest Habitat Selection by Eight Syntopic Species of Mediterranean Gulls and Terns. Colonial Waterbirds, 15 (2): 169-178.

Fasola M., Bogliani G., Saino N. \& Canova L., 1989a Foraging, feeding and time activity niches of eight species of breeding birds in the coastal wetlands of the Adriatic Sea. Bollettino di Zoologia, 56 (1): 6172.

Fasola M., Saino N., Canova L. \& Bogliani G., 1989b Breeding and summering population of gulls and terns in coastal wetlands of the Adriatic Sea. Le Gerfaut, 79: 177-184.

Flather C. H., Hayward G. D., Beissinger S. R. \& Stephens P. A., 2011 - Minimum viable populations: is there a "magic number" for conservation practitioners? Tren$d s$ in Ecology \& Evolution, 26 (6): 307-316.

Fracasso G., Verza E. \& Boschetti E., 2003 - Atlante degli Uccelli nidificanti in provincia di Rovigo. Provincia di Rovigo.

Frederick P., Heath J, Bennetts R. \& Hafner H., 2006 Estimating nests not present at the time of breeding surveys: an important consideration in assessing nesting populations. Journal of Field Ornithology, 77 (2): 212-219.

Gochfeld M., Burger J., Kirwan G. M. \& Garcia E. F. J., 2017 - Common Gull-billed Tern (Gelochelidon nilotica). In: Handbook of the Birds of the World Alive. del Hoyo J., Elliott A., Sargatal J., Christie D. A. \& de Juana E. (eds.). Lynx Edicions, Barcelona. <http:// www.hbw.com/node/54012> (retrieved on 7 October 2017).

Grussu M. 1995 - Status, distribuzione e popolazione degli uccelli nidificanti in Sardegna (Italia) al 1996 (Prima parte). Gli Uccelli d'Italia, 20: 77-85.

Grussu M. \& Gruppo Ornitologico Sardo, 2017 - Gli uccelli nidificanti in Sardegna. Status, distribuzione e popolazione aggiornati al 2016. Aves Ichnusae, 11: 3-49.

Gustin M., 1988 - Nidificazione della Sterna zampenere nella provincia di Oristano (Sardegna occidentale). Avocetta, 12: 122-123.

Gustin M., Brambilla M. \& Celada C., 2016 - Stato di conservazione e valore di riferimento favorevole per le popolazioni di uccelli nidificanti in Italia. $R I O-R i$ vista italiana di ornitologia, 86: 3-58. <https://doi. org/10.4081/rio.2016.332>

Lepori C., 1882 - Contribuzioni allo studio dell'Avifauna sarda. (Prima parte: 293-320). (Continuazione e fine: 321-345). Atti Società italiana di Scienze Naturali, 25: 293-345.

Massa B. \& Schenk H., 1983 - Similarità tra le avifaune della Sicilia, Sardegna e Corsica. Lavori Società di Biogeografia, VIII (1980): 757-799. 
Marinov M., Dorosencu A., Alexe V., Bolboaca L. E., Kiss J. B., Nanu C., Tosic K. \& Tudor M., 2019 Recent data regarding colonial waterbirds in Danube Delta Biosphere Reserve (Romania). Journal of Environmental Protection and Ecology, 1: 276-284.

Mocci Demartis A., 1973 - Avifaune du Campidano d'Oristano (Sardaigne). Alauda, 41: 35-62.

Molina K. \& Erwin R. E., 2006 - The Distribution and Conservation Status of the Gull-billed Tern (Gelochelidon nilotica) in North America. Waterbirds, 29: 271295.

Nardelli R., Andreotti A., Bianchi E., Brambilla M., Brecciaroli B., Celada C., Dupré E., Gustin M., Longoni V., Pirrello S., Spina F., Volponi S. \& Serra L., 2015 Rapporto sull'applicazione della Direttiva 147/2009/ $\mathrm{CE}$ in Italia: dimensione, distribuzione e trend delle popolazioni di uccelli (2008-2012). ISPRA, Serie Rapporti, 219/2015.

Palacios E. \& Mellink E., 2007 - The colonies of Van Rossem's Gull-billedTern (Gelochelidon nilotica vanrossemi) in México. Waterbirds, 30 (2): 214-222.

Pannekoek J. \& van Strien A. J., 2005 - TRIM 3 Manual. Trends and indices for monitoring data. Research paper no. 0102. CBS, Statistics Netherlands. Voorburg, The Netherlands.

Peronace V., Cecere J. G., Gustin M. \& Rondinini C., 2012 - Lista Rossa 2011 degli Uccelli Nidificanti in Italia. Avocetta, 36 (1): 11-58.

Pin C., 2018 - Lettre d'information réseau de gestionnaires et de suivi laro-limicoles. $<$ http://www.life-envoll. eu> (Décembre 2018).

Radi M., Qniba A., Znari M., Aourir M., El Idrissi A. \& Daki M., 2011 - Étude de la Sterne Hansel Gelochelidon nilotica au Maroc central: reproduction, régime alimentaire et impact de l'activité humaine. Alauda, 79 (4): 269-284.

Sadoul N., 2016 - Restitution du suivi 2016 de la reproduction des laro-limicoles coloniaux. <http://www. life-envoll.eu>

Sánchez J. M., Munoz del Viejo A., Corbacho C., Costillo E. \& Fuentes C., 2004a - Status and trends of Gullbilled Tern Gelochelidon nilotica in Europe and Africa. Bird Conservation International, 14 (4): 335-351.

Sánchez J. M., Corbacho C., del Viejo A. M. \& Parejo D., $2004 \mathrm{~b}$ - Colony-site tenacity and egg color crypsis in the Gull-billed Tern. Waterbirds, 27 (1): 21-30.

Scarton F. \& Valle R., 2015 - Long-term trends (19892013 ) in the seabird community breeding in the lagoon of Venice (Italy). RIO - Research in Ornithology, 85 (2): 21-30. < doi.org/10.4081/rio.2015.232>

Scarton F., Cecconi G., Cerasuolo C. \& Valle R., 2013 The importance of dredge islands for breeding waterbirds. A three-year study in the Venice Lagoon (Italy). Ecological Engineering, 54: 39-48.

Scarton F., Verza E., Guzzon C., Utmar P., Sgorlon G. \& Valle R. G., 2018 - Laro-limicoli (Charadriiformes) nidificanti nel litorale Nord Adriatico (Veneto e Friuli Venezia Giulia) nel periodo 2008-2014: consistenza, trend e problematiche di conservazione. RIO - Research In Ornithology, 88 (2): 33-41. < doi.org/10.4081/ rio.2018.418>
Schenk H., 1976 - Analisi della situazione faunistica in Sardegna. Uccelli e Mammiferi. In: S.O.S. Fauna. Animali in pericolo in Italia. Pedrotti F. (a cura di). WWF, Camerino: 465-556.

Sears H. F., 1978 - Nesting behavior of the Gull-billed Tern. Bird Banding, 49: 1-16.

Steinkamp M., Peterjohn B., Byrd V., Carter H. \& Lowe R., 2003 - Breeding season survey techniques for seabirds and colonial waterbirds throughout North America. $<$ http://www.waterbirdconservation. org./pubs/ PSGManual03.PDF>

Valle R. \& Scarton F., 1999 - Habitat selection and nesting association in four species of Charadriiformes in the Po Delta (Italy). Ardeola, 46 (1): 1-12.

Valle R. G. \& Scarton F., 2018 - Uso dei droni nel censimento degli uccelli acquatici nidificanti nel Nord Adriatico. Bollettino del Museo di Storia Naturale di Venezia, 69: 69-75.

Valle R. G., Scarton F. \& Sattin L., 2017 - Insediamento recente di sterna zampenere (Gelochelidon nilotica) in laguna di Venezia: analisi delle informazioni. Lavori Società Veneziana di Scienze Naturali, 42: 21-24.

Verza E., 2015 - Popolazione e scelta dell'habitat riproduttivo di Pernice di mare Glareola pratincola e Sterna zampenere Gelochelidon nilotica nella parte veneta del Delta del Po (Rovigo); analisi del periodo 2001-2012. In: XVII Convegno Italiano di Ornitologia. Trento, 11-15 settembre 2013. Atti del convegno. Pedrini P., Rossi F., Bogliani G., Serra L. \& Sustersic A. (a cura di). Ed. MUSE, Trento: 75-77.

Vořišek P., Klvaňova A., Wotton S. \& Gregory R. D. (eds.), 2008 - A best practice guide for wild bird monitoring schemes. First edition, CSO/RSPB.

Walter H., 1964 - Vögel an sardischen Salinen. Bonner Zoologische Beiträge, 15: 198-210.

Wang Q. X., Xiao H., Wang Z. Q. \& Hu C. E., $2010-$ Comparative studies on breeding ecology of Sterna hirundo and Gelochelidon nilotica in Hongjiannao Lake, Shaanxi Province. Chinese Journal of Zoology, 45 (2): 39-45.

Windhoffer E. D., Owen T. M., Liechty J. S., Minor A. K., Curtiss D. K., Nepshinsky M. \& Pierce A. R., 2017 Variability in Gull-Billed Tern (Gelochelidon nilotica) Breeding Parameters at the Isles Dernieres Barrier Islands Refuge, Louisiana, USA. Waterbirds, 40 (4): 390-395. 